\title{
English-Indonesian Subtitling Strategies of Lara Jean's Utterances in "To All the Boys: Always and Forever" Movie on Netflix
}

\author{
${ }^{1}$ Tiffani Rizki Putri Baihaqi, ${ }^{2}$ Agus Subiyanto \\ ${ }^{1,2}$ Master's Program in Linguistics, Faculty of Humanities, Diponegoro University, \\ Semarang, Indonesia \\ 1tiffanirpb@gmail.com \\ ${ }^{2}$ subaling@gmail.com
}

Article History: Submitted August 13 $3^{\text {th }}, 2021$; Accepted November $8^{\text {th }}, 2021$; Published November 27 th $^{\text {th }} 2021$

\begin{abstract}
Streaming platforms, such as Netflix, gained their popularity significantly during the pandemic prominently since people avoid watching films in theatres. Thus, the study of translation, specifically subtitling, is necessary since there will be more films with different languages to be produced and streamed by people from different countries. This research aims to study and interpret the subtitling strategies used on Netflix, specifically in "To All the Boys: Always and Forever" movie. Employing a qualitative library research method and document analysis for the data collecting technique, this research unveils the subtitling strategies as well as the subtitle quality of Lara Jean's utterances in "To All the Boys: Always and Forever" film on Netflix. The data source is chosen since the film is considered popular as it is the adaptation of the best-selling novel "Always and Forever, Lara Jean." From the 428 utterances, it is discovered that there are seven strategies applied; respectively paraphrase, transfer, condensation, deletion, expansion, imitation, and transcription. Meanwhile, three strategies that are not found are decimation, dislocation, and resignation. Paraphrase is the most frequently applied strategy since many utterances require localization and alteration to become clearer for the Indonesian audience. On the other hand, decimation, dislocation, and resignation are not used respectively due to the rate of the film, translatable utterances, and soundtracks that are not translated.
\end{abstract}

Keywords: film; netflix; subtitling strategies; subtitling quality; translation

Abstrak. Layanan streaming, seperti Netflix, meraih popularitas secara signifikan selama pandemi karena masyarakat menghindari menonton film langsung di bioskop. Oleh karena itu, penelitian mengenai terjemahan, khususnya subtitling, diperlukan karena film dalam bahasa asing akan semakin banyak diproduksi dan ditonton oleh orang-orang dari berbagai negara. Penelitian ini bertujuan untuk mengkaji dan memaknai strategi subtitling yang digunakan oleh Netflix, khususnya pada film "To All the Boys: Always and Forever." Penelitian ini menggunakan metode deskriptif kualitatif dan mengungkap strategi serta kualitas subtitling dari ucapan Lara Jean dalam trilogi "To All the Boys: Always and Forever" di Netflix. Sumber data tersebut dipilih karena film yang dianggap populer ini merupakan adaptasi dari novel "Always and Forever, Lara Jean." Dari 428 ujaran, terdapat tujuh strategi yang diterapkan, yaitu parafrase, transfer, pemampatan, penghapusan, penambahan, imitasi, dan transkripsi. Sedangkan tiga strategi yang tidak diterapkan yaitu desimasi, dislokasi, dan angkat tangan. Parafrase merupakan strategi yang paling banyak ditemukan karena terdapat banyak ujaran yang disesuaikan dengan konteks lokal dan diubah agar menjadi lebih jelas bagi penonton Indonesia. Sementara itu, desimasi, dislokasi, dan angkat tangan tidak digunakan karena kategori film, ujaran yang dapat diterjemahkan, dan lagu yang tidak diterjemahkan.

Kata kunci: film; kualitas subtitling; netflix; strategi subtitling; terjemahan 


\section{INTRODUCTION}

Within the past fifteen years, audiovisual translation has been the most rapidly growing strand of translation studies. Subtitling is within the audiovisual translation, as others are revoicing (subbing, voice-over, narration, free commentary, and simultaneous interpreting), and assistive forms of audiovisual translation (audio description) (Pérez-González, 2014). Subtitle, referring to (Khalaf, 2016), means a type of translation, specifically in the field of audiovisual that involves voice-over, dubbing, and audio description. Similarly, Abdelaal defined subtitles as texts of the same language (intralingual subtitling) or different language (interlingual subtitling) that pop up on the screen (Abdelaal, 2019). A subtitle is the product of subtitling. Hastuti stated that subtitling is done by transferring the speakers' dialogues and putting them in a form of texts, which are displayed at the bottom of the scenes (Hastuti, 2015). (Cintas, 2012)

Hariyanto emphasized that the main purpose of subtitling is to assist the audience in watching their films (Hariyanto, 2005). In addition, the presence of subtitles in films is not only necessary for people who do not understand the source language, but also for people with hearing loss (Khalaf, 2016). In foreign language learning, subtitles are utilized as a medium for language acquisition both in a formal class or an informal setting (Almeida \& Costa, 2014). Gottlieb presented the idea that in creating subtitles, the focus and priority are on the speech act, while visual effects and verbal intentions are more vital than individual lexical elements (Gottlieb, 2001). However, there is never a perfect translation as different languages bring their grammatical structure, vocabulary range, and their countries' cultural references. Subtitlers must keep in mind that even synonyms of the same language are mostly always near-synonyms instead of exact equivalents (Cintas \& Ramael, 2021). Besides the language constraints, each subtitler has his or her own biases and so a translation is never neutral as it must be the bridge between the two different worlds (Cintas, 2012). Aside from the linguistic system differences and bias, a subtitler can employ ten subtitling strategies as proposed by Gottlieb to produce a quality subtitle that is informative, entertaining, and involving (Gottlieb, 1992). Meanwhile, subtitling strategy is defined as the technique employed by translators in translating the speaker's utterances (Hastuti, 2015). The subtitling strategies that are proposed by Gottlieb are expansion, paraphrase, transfer, imitation, transcription, dislocation, condensation, decimation, deletion, and resignation (Gottlieb, 1992).

Hariyanto stated that the aim of using subtitling strategy is to solve some subtitling problems, namely language, socio-cultural context, limited layout, and time appearance (Hariyanto, 2005). This theory is in line with the ten subtitling strategies proposed by Gottlieb to make subtitlers, consciously or not, reach an adequate and the most equivalent product of subtitles (Gottlieb, 1992). The first strategy is expansion, which means adding necessary information to expand the expression, prominently due to the culture-specific references that are not available in the target language. The second strategy is a paraphrase, which is used when there is a non-visualized language-specific phenomenon that needs an altered expression. It is done by changing the sentence structure yet still maintaining the same meaning. The third one is a transfer, which means to translate it into full expression. In other words, the sentence is translated precisely and accurately. The fourth strategy is imitation, which is used for translating proper nouns and international greetings. It is done by rewriting the expressions. The fifth one is transcription, which is applied for non-standard speech such as third or non-sense language. The sixth strategy is dislocation, which is used prominently to translate musical and visual languagespecific phenomena. In other words, it is applied when the effect of the translation needs to be emphasized rather than the content (Adinusa \& Asmarani, 2018). The seventh strategy is condensation, which is done by omitting unnecessary text to make it shorter without losing the intended meaning. The eighth strategy is decimation, which is used by eliminating a fast speech or 
taboo words that occur during a fight scene. The ninth strategy is deletion, which is done by omitting expressions that are considered not important. The last strategy is resignation, which occurs when there is no solution to the translation, and this could be due to untranslatable elements.

Numerous studies from around the world within the past ten years regarding subtitling strategies that used films, videos, and TV series from various genres prove that the matter is prominent in the fields of linguistics, specifically subtitling. First, Issues and Strategies of Subtitling Cultural References "Harry Potter" Movies in Arabic (Altahri, 2013), which stated that the typology of the language used in Harry Potter involves borrowing frequently terms from many myths and legends around the world. Moreover, there are many usages of alliterations of characters and products names on the series to make the readers easy to remember. Wordplay such as "the Ordinary Wizarding Levels exam, 'O. W. L" is also a challenge for the translators. The second research is Strategies in Subtitling English Cartoons or Animations (Hosseinnia, 2014), which mentioned that the transfer strategy is used in $38.2 \%$ of the subtitles being observed, making it the most frequent strategy applied. Meanwhile, the least common strategy used is a transcription with $1.3 \%$ of the subtitles. Third, An Analysis of the Subtitling Strategies of "Romeo And Juliet" Movie (Hastuti, 2015), discovered that the most frequently used strategy is the condensation strategy due to limited subtitling time appearance and limited characters. Additionally, context plays an important part in subtitling since the subtitlers must have the cultural understanding of both cultures to appropriately transfer the message from the source language into the target text. The fourth is Challenges and Strategies of Subtitling Humour: A case study of the American sitcom "Seinfeld" with particular reference to English and Arabic (Altahri, 2013), which found out that there are some considerations from the subtitlers in choosing the subtitling techniques, such as the intersemiotic redundancy, the use of taboo words, temporal and spatial restrictions, intertextuality, extratextuality, visual elements, the linguistic and cultural gap between English and Arabic languages and cultures, the simplicity of the humor, and the target text (TT) audience's knowledge of the show. To tackle those problems, the subtitlers then applied some strategies so that they can be accepted by the TT's audience. Some of the strategies are official equivalent, paraphrase, omission, addition, reduction, explicitation, generalization, lexical creation, substitution, euphemism, using punctuation, and retention.

Next, Subtitling Strategies in "Real Steel” Movie (Simanjuntak \& Basari, 2016), which stated that amongst the six strategies applied, deletion strategy (18 utterances or 29.03\%) is the most frequently used strategy by the subtitlers. Deletion is useful to keep the subtitling short but meaningful. Sixth, An Analysis of Subtitling Strategy in the "La La Land" Movie (2016) (Dhari et al., 2016), which found out a similar result from the previous research, that deletion strategy is the most frequently used strategy applied in subtitling the film. Seventh, Subtitling Strategies of Po's Utterances in "Kung Fu Panda" Movie (Adinusa \& Asmarani, 2018), which asserted that amongst the 345 utterances, transfer strategy is the most frequently applied strategy (186 or 53.91\%). The transfer strategy is used to translate the text completely and accurately so that the audience can grasp the whole message of the source language. Next, Procedures Used in Translating Cultural Words of the Movie "Eat Pray Love" (Halim \& Asmarani, 2019), which mentioned that borrowing, either pure or natural borrowing, is the procedure that the subtitlers used the most. Some of the borrowed words in the movie are nachos, tequila, lottery, and kremasi. Meanwhile, literal and transposition are the least used procedures applied by the subtitlers. Ninth, Pubg Fansubtitle: Strategies and Translation Acceptability (Puri \& Pasaribu, 2019), which found that the subtitling strategies applied in the film are expansion, transfer, paraphrase, transcription, imitation, decimation, condensation, resignation, deletion, and taming. Similar to the aforementioned research, transfer strategy is applied to produce 
a correct and complete translation. As for the subtitle quality, ideal-acceptable translation is found on $80.2 \%$ of the data, making it mostly acceptable.

Tenth, Subtitling Strategies in "The Boss Baby: Back in Business” Series (Kholiq \& Agustine, 2020), which discovered that condensation strategy ( $50 \%$ of the data) is the most frequently used strategy. Meanwhile, the least used strategies are paraphrase, transfer, and transcription. Next, Subtitling Techniques and the Quality of Indonesian Subtitles of "The English Teacher" (Hudi et al., 2020), which stated that literal translation is the most frequently used strategy $(81.88 \%)$. As for the subtitle quality, it was found that mostly, the subtitles are accurate $(67.50 \%)$, acceptable $(79.08 \%)$, and readable $(85.85 \%)$. The last research that was conducted on the topic of subtitling strategies is Subtitling Strategies of Swear Words in Deadpool One \& Deadpool Two Film (Rohmawati, 2021). The research explained that the inevitable cultural differences between America and Indonesia in subtitling must be faced with the appropriate strategies. In fact, sometimes it is impossible to find the equivalent swear words in the TT.

Furthermore, movies have grown to become one of the most influential and widely-spread forms of art (Matkivska, 2014). As a result, streaming platforms are getting more popular than ever. The phenomenon is supported by the situation during the pandemic, where people spend most of their time at home. Inevitably, watching films at home is one of the entertaining activities to be done during the lockdown in many countries. As people are advised to stay at home as long as they can, streaming platforms help to cope with the restriction. According to BBC News, there are 16 million new users of Netflix, a rising streaming platform. In addition, the company possesses more than 182 million subscribers worldwide. Through films, someone can feel that they experience what the characters in the film experience. In addition, there is a chance that streaming will be the future of entertainment (Richards, 2021). Therefore, studying subtitling strategies in films is worthy as many people encounter it daily and the global streaming platform industry is rising.

The present research discusses the subtitling strategies as well as the subtitle quality of a film titled "To All the Boys: Always and Forever," which was directed by Michael Fimognari in 2021. The film was based on a best-selling novel written by Jenny Han titled "Always and Forever, Lara Jean." The film chronicles the early adulthood of Lara Jean who is soon graduating from Senior High School and going to college, as she encounters her college options and faces some doubts in considering how she will be far away from her boyfriend and family. On the other hand, she is eager to pursue her dream to study English Literature in her dream campus, even though it might distance her from her loved ones. The film is chosen to differentiate the present research from the previous research and to give novelty of the object being examined, as it is a current film.

Since subtitles are essential to connect and communicate with an international audience, examining the subtitling strategies employed by Netflix along with its quality undoubtedly contributes to the applied linguistics field, specifically within the topic of subtitling. Moreover, by knowing the subtitling quality, subtitlers can assess what to improve. In other words, they can discover room for improvement that can be useful for future research or subtitling projects.

\section{METHOD}

This research used qualitative library research method and document analysis for the data collecting technique to discover the subtitling strategies as well as the subtitle quality of Lara Jean's utterances in "To All the Boys: Always and Forever" film on Netflix. Descriptive research is a method that 
systematically and accurately explains existing phenomena to thoroughly discover the answers to the designated research questions (Atmowardoyo, 2018). Furthermore, Bowen added that document analysis is a systematic procedure to evaluate and review both printed and electronic documents, which can be Internet-transmitted or computer-based materials (Bowen, 2009). The scrutinized documents consisted of scenes and texts in a form of subtitles, which were recorded without any intervention from the researcher. The documents in this research provided the data which then could be studied.

Library research covered the identification of sources with necessary components for the research (George, 2008). The information is obtained through written documents, photographs, pictures, and electronic documents that can support the research process. As this research used the film and the subtitles as the primary subjects, library research was employed to obtain in-depth analysis using the theories and prior studies as secondary sources.

For the subtitle quality, the researcher handed expert judgment forms to four subtitles at an established translation, proofreading, and subtitling company in Yogyakarta. The form consists of accuracy and acceptability rates.

The film was obtained through a streaming platform named Netflix, with the email address akbararyo@gmail.com, to prove it is from an original and legal source. The duration of the film is 1 hour and 55 minutes. The theory employed in this research is the subtitling strategy as proposed by Gottlieb. In collecting the data, the researcher watched the film as well as juxtaposed the English and Indonesian texts. After the data was collected, the researcher studied the strategy of subtitling by referring to Gottlieb's theory. Finally, the researcher counted the number of verbal segments of each subtitling strategy and presented the frequency ascendingly in a table.

\section{RESULTS AND DISCUSSION}

The obtained results are elaborated in this part. From a total of 1 hour and 55 minutes, 428 utterances were found in "To All the Boys: Always and Forever." Those utterances consist of seven subtitling strategies as proposed by Gottlieb, which are paraphrase, transfer, condensation, deletion, imitation, expansion, and transcription (Gottlieb, 1992). Meanwhile, three of his strategies are not found in the film, which were decimation, dislocation, and resignation. The results are similar to some of the previously done research, stating that this research strengthens Gottlieb's subtitling strategy theory.

The employment of Gottlieb's theory gave the overview of the film. Paraphrase is the most repeatedly used strategy in subtitling the film since the subtitler is required to alter and localize the text so it is shorter, effective, and accurate, but maintains the core message. On the contrary, considering only one cultural reference and a third language that Lara Jean spoke of, expansion and transcription are the least used subtitling strategies. In addition, decimation is not applied due to the film's PG-13 rating as it contains no taboo words. PG-13 means parents' guides are strongly suggested because some materials might be inappropriate for pre-teenagers (Rating Guide, 2020). Meanwhile, resignation is not used either since there are no untranslatable words or phrases, as all of Lara Jean's utterances are translated properly using the seven strategies. Moreover, dislocation is not applied because the object of the research, which is the main character named Lara Jean, did not utter any songs in the film, thus musical and visual language-specific phenomena are not found. 


\section{Subtitling Strategies}

Employing Gottlieb's theory of subtitling strategies, amongst the 428 utterances, there are seven out of ten strategies that are discovered on the film as elaborated in Table 1 below.

Table 1 Subtitling Strategies in "To All the Boys: Always and Forever"

\begin{tabular}{lll}
\hline \multicolumn{1}{c}{ Type of strategy } & \multicolumn{1}{c}{$\begin{array}{c}\text { Number of verbal } \\
\text { segments }\end{array}$} & Frequency \\
\hline Paraphrase & 122 & $28.50 \%$ \\
Transfer & 109 & $25.47 \%$ \\
Condensation & 91 & $21.26 \%$ \\
Deletion & 71 & $16.59 \%$ \\
Imitation & 33 & $7.71 \%$ \\
Expansion & 1 & $0.23 \%$ \\
Transcription & 1 & $0.23 \%$ \\
\hline & 428 & $100.00 \%$ \\
\hline
\end{tabular}

The above table depicts the subtitling strategies employed in the film "To All the Boys: Always and Forever," from the most to the least commonly used strategies. A thorough explanation of each subtitling strategy along with the examples a well as the context of each utterance are presented as follows:

\section{Paraphrase}

Paraphrase, according to the Oxford Learner's Dictionary, means "to express what somebody has said or written using different words, especially to make it easier to understand" (Paraphrase, n.d.). In subtitling, it is used when there is a non-visualized language-specific phenomenon that needs an altered expression. It is done by changing the sentence structure yet still maintaining the same meaning. In the film, paraphrase strategy is applied on 122 (28.50\%) of Lara Jean's utterances, making it the most frequently used strategy in subtitling the film. It is arguably because the subtitler has to adjust some words in the sentences so it is shorter, accurate, and effective, but maintains the message. Examples are written below to explain the findings:

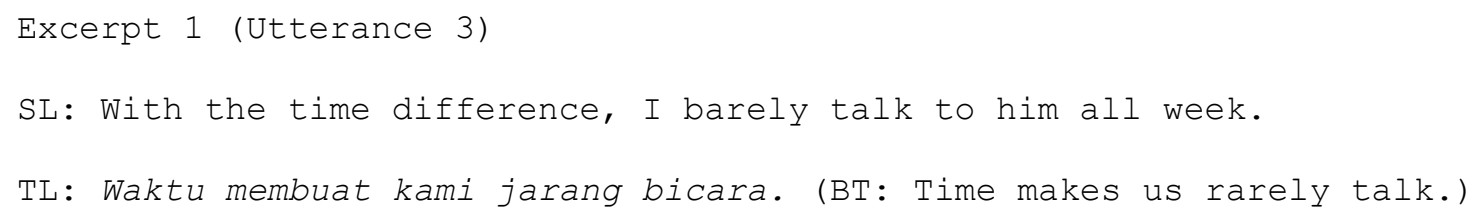

In Utterance 3, Lara Jean complained to her sisters about the time difference between Seoul, where she currently spent the holiday with her family, and California, where her boyfriend visited Stanford University. The paraphrase strategy is applied in the excerpt above to create a more understandable and shorter sentence. The source language, if translated literally, would result in a much longer Indonesian sentence "Dengan perbedaan waktu, aku jarang berbicara kepadanya seminggu." Compared to the subtitles "Waktu membuat kami jarang bicara," it is more natural to be used in spoken language and more effective because it only conveys the core message of the utterance. Displaying fewer words in the subtitle is beneficial for the audience since the duration for its appearance is only approximately less than 3.5 seconds (Hariyanto, 2005). 
SL: As you were.

TL: Kembali ke tempat. (BT: Go back to your seat.)

According to Collins English Dictionary, the phrase "as you were" means "return to the previous position" (As You Were, n.d.). Paraphrase is used in the excerpt above to adjust it to the equal Indonesian phrase "kembali ke tempat." The Indonesian subtitle is more literal, stating the word "tempat" (place) which refers to Lara Jean's family's chairs, and implies Lara Jean's intention to leave the dining table and ask their family to continue eating without her. The strategy is appropriate to be used because it makes the utterance clearer to the Indonesian audience.

Excerpt 3 (Utterance 111)

SL: Oh no.

TL: Ya ampun. (BT: My goodness.)

In Utterance 111, Lara Jean was shocked that she texted the wrong number. She meant to send the text to Margot, her older sister, but accidentally sent it to Peter, which caused a misunderstanding between them. The wrong message then resulted in Peter assuming she got into Stanford, while in fact she got rejected, which later led to unfortunate events between the couple. Lara Jean said "Oh no" to express her clumsiness. It is translated to "ya ampun," which is not the literal meaning. However, the subtitle conveys the same message and brings the same panic atmosphere. The phrase "ya ampun" or "my goodness" is an acceptable and widely used expression to state someone's feeling of shock. Compared to the literal translation of "oh no," which is "oh tidak," the subtitle is more suitable, and therefore it is appropriate for the subtitler to apply the paraphrase strategy.

Excerpt 4 (Utterance 133)

SL: You know, Tri, this whole stepmom thing suits you.

TL: Tri, kau cocok menjadi ibu tiri. (BT: Tri, you're perfect for being a stepmom.)

In Excerpt 5, paraphrases are used to make the utterance more effective and comprehensible for the Indonesian audience. Cintas stated that a subtitler should avoid unnecessary redundancy and consider that the translated sentence represents the information that is uttered (Cintas, 2012). Unnecessary words are often uttered as filler words, which need to be omitted so the translated version is shorter. In Utterance 133, "you know" and "this whole thing" are respectively redundant and have no equal Indonesian phrase, thus need to be omitted. To translate the utterance effectively, the most suitable strategy is by paraphrasing the main idea of the sentence to be "Tri, kau cocok menjadi ibu tiri" (BT: Tri, you're perfect for being a stepmom).

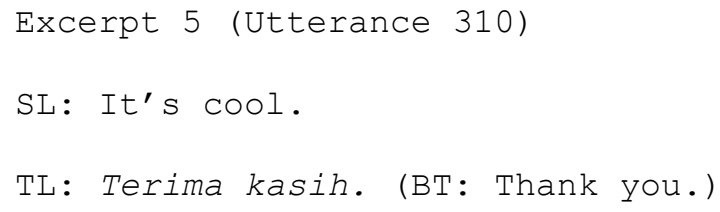

In the above excerpt, Lara Jean and Peter took their prom photo at school. Lara Jean said to the photographer "It's cool" at the end of their photo session. In Indonesia, "It's cool" literally translates 
to "itu keren." Meanwhile, Lara Jean said the utterance to thank the photographer. There is a major change in the translation, not only in the phrase that Lara Jean used but also in the literal meaning. In Indonesia, if someone wants to show appreciation and gratitude, most likely, he or she would directly say the word "thank you." Therefore, the appropriate translation for the utterance "it's cool," is by localizing the text to "terima kasih" or "thank you" to signify and make it clear that Lara Jean intended to show her gratitude and appreciation. So, the paraphrase strategy is used in translating Utterance 310 to make it clearer for the Indonesian audience.

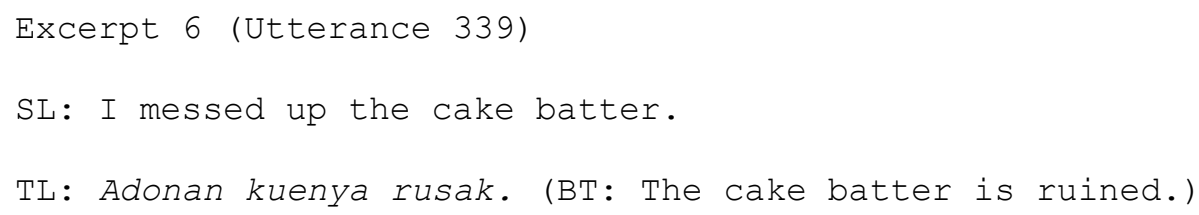

In the above excerpt, Lara Jean complained to her father about her failed dough. She tried to bake her parents' wedding cake. Then, she said that she ruined the cake batter because unfortunately, the dough is still too crunchy for a cake. Paraphrase is used in translating Utterance 339 above to make it more effective and comprehensible. A subtitle needs to be effective since the audience must finish reading the written subtitles at a given time while watching the scenes at the same time (Cintas, 2012). In addition, Cintas \& Ramael pointed out that there must be enough time for the audience to combine reading with watching and listening so that they can revel in the scenes as well as listen to the music that accompanies the film (Cintas \& Ramael, 2021).

\section{Transfer}

Transfer means to translate in full expression. In other words, the sentence is translated precisely and accurately. Transfer strategy is the second most often used strategy as the subtitler needs to get the target language as close as possible to the source language. In the film, there are 109 verbal segments or $25.47 \%$ of Lara Jean's utterance subtitles that employ this strategy. Transfer strategy is often found in short sentences like the utterances in the following excerpts. Further explanation of the findings are explained below:

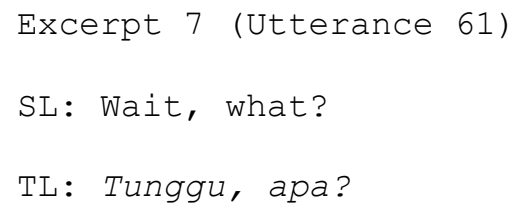

In subtitling Utterance 61, the subtitler employed a transfer strategy. Looking at the context of the utterance, Lara Jean who had just woken up after accidentally falling asleep while watching a film at home with Peter was shocked to know that it was already past midnight. The word "wait" is "tunggu" in Indonesian, as well as "what" translates to "apa." The utterance is transferred accurately and precisely because each word from the source language to the target language is constructed in the same structures. There are no omissions or additions in the target language. The question mark is also maintained to preserve the intention of the utterance, which is to express surprise, an indirect function of interrogative sentences (Fareh \& Moussa, 2008). The utterance then is followed by Peter going home due to Lara Jean's father's time restriction for him to stay at her house.

Excerpt 8 (Utterance 112)

SL: Peter, what are you doing? 


\section{TL: Peter, apa yang kau lakukan?}

Looking at the context of the utterance, Lara Jean who had just sent a wrong text message to Peter, which created a misunderstanding between them, was trying to act cool by asking Peter what he was doing in front of her house. Peter, who thought Lara Jean was going to the same college as him, surprised her by loudly playing a song on his radio. The word "Peter" is a proper noun, so it is written the same in the subtitles. Meanwhile, the word "what" literally means "apa," and "are" could be translated to "yang," "you" is "kau," and "doing" is "lakukan." So, the strategy used in translating Lara Jean's utterance is transfer, since the result is literal and the structure of the sentence stays the same. It brings not only the message of the utterance but also successfully illustrates the awkward atmosphere of Lara Jean in that unfortunate moment.

Excerpt 9 (Utterance 149)

SL: You can be honest.

TL: Kau boleh jujur.

Transfer strategy is also applied in Utterance 149 above. The word "you" means "kau", the phrase "can be" is defined as "boleh", and "honest" translates to "jujur." Referring to the context, Lara Jean asked the question to Kitty, her little sister, on what scale will she miss Lara Jean when she is studying abroad. She added that Kitty could be honest in answering the question, to which she replied jokingly by saying she will miss Lara Jean on a scale of 4 out of 10. The word per word translation in this utterance is suitable to be used in the context because Lara Jean intends to not give pressure to Kitty so she can answer honestly without pretending.

Excerpt 10 (Utterance 275)

SL: Don't worry.

TL: Jangan khawatir.

Transfer strategy is also applied in Utterance 275. Lara Jean was on the phone with her older sister, Margot. She told Margot not to worry about her decision to go to Berkeley. An expression like "Don't worry" is translated to "Jangan khawatir" in Indonesian. Besides having the same meaning, the subtitle version also possesses the same structure despite using different parts of speech. "Don't" is an auxiliary verb, while "Jangan" is an adverb. Meanwhile, "worry" and "khawatir" are both adjectives. However, the meanings are accurately and effectively conveyed in the subtitles.

Excerpt 11 (Utterance 361)

SL: That's not true.

TL: Itu tidak benar.

Transfer strategy is also applied in Utterance 361 above. Lara Jean stated her disagreement towards Peter about his opinion on signing yearbooks by saying "that's not true." The word "that's" literally translates to "itu", the word "not" literally translates to "tidak", and "true" literally translates to "benar." Short utterances like so are suitable to be translated using transfer because they are mostly an effective and clear sentence. On the other hand, if it is translated using other strategies, the results might be inaccurate and ineffective. 


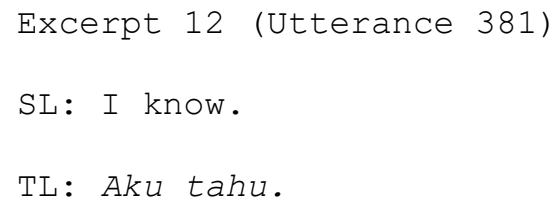

In the above excerpt, the subtitling strategy that is used is transfer because the Indonesian subtitle displays the exact structure and meaning. Echoing the definition of subtitling proposed by Hastuti transfer is frequently used since the aim of subtitles is to convey as equally as possible, not only the message but also the sentence (Hastuti, 2015). The word "I" literally means "aku" and "know" translates to "tahu." The context of the utterance is when Lara Jean invited Peter to come to her house even though it was almost past curfew. Peter reminded her, and she answered with "I know," indicating she did not care about the rule anymore. The subtitler employed the strategy because the speaker said a short phrase with direct meaning, making it unnecessary to shorten or paraphrase the utterance. Therefore, utterance 381 is appropriate and suitable to be translated using transfer strategy.

\section{Condensation}

According to Cintas, condensation "relies on a more concise rendering of the original." Condensation is done on normal speeches by omitting unnecessary text and making a shorter version of the utterance by leaving only the main ideas (Cintas, 2012). Cintas emphasized that in written subtitles, there is a tendency for the oral speech to be trimmed, making condensation to be "the core strategy in use" (Cintas, 2012). In addition, Cintas \& Ramael wrote that within the mainstream commercial subtitles, the written version of utterance is mostly a condensed form of the oral ST, even though it must be emphasized that the omission might be different across countries along with companies and that reading speeds are high in some contexts (Cintas \& Ramael, 2021). There are 91 (21.26\%) of Lara Jean's utterances in the film which were translated using condensation strategy. Below are some examples to interpret and elaborate the findings:

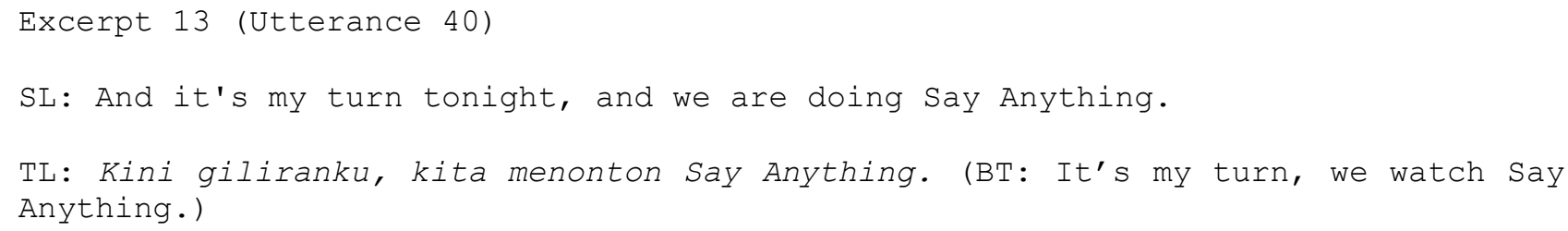

Condensation is used by the subtitler for Utterance 40 to obtain a shorter sentence by only showing the main ideas of Lara Jean's sentence. The context of the utterance is Lara Jean and Peter have a movie routine and they take turns in selecting the title of the film. The word "tonight" serves as an intensifier as it is used by Lara Jean to emphasize that on that particular night, it is her turn to choose the movie. However, in this context, the word "tonight" can be omitted without affecting the gist of the utterance. It is also due to their movie routine which always happens at night. In her turn, Lara Jean suggested a film titled "Say Anything." The literal translation of the utterance would be "Dan kini giliranku, dan kita menonton "Say Anything"." Compared to the subtitles, the literal translation has more words due to the repetition of the unnecessary word "and" or "dan." With fewer morphemes, the subtitler conveyed the same meaning of Lara Jean's utterance using the condensation strategy.

Excerpt 14 (Utterance 49)

SL: That doesn't count 'cause we already knew each other. 
TL: Itu tak termasuk karena kita saling kenal. (BT: That doesn't count because we knew each other.)

Similar to the paraphrase strategy, in the above excerpt, condensation is applied by the subtitler to obtain a shorter sentence but still maintain the message. The context of the utterance is Lara Jean talking about Peter and her "meet-cute" or the moment of their first meeting. She thought they did not have a meet-cute because they had known each other for a very long time, making her forget their first meeting. The literal translation of the utterance would be "Itu tak termasuk karena kita sudah saling kenal." Compared to the subtitles, the literal translation possesses more words. So, employing the condensation strategy, the subtitler can convey the same meaning of the utterance but with fewer words.

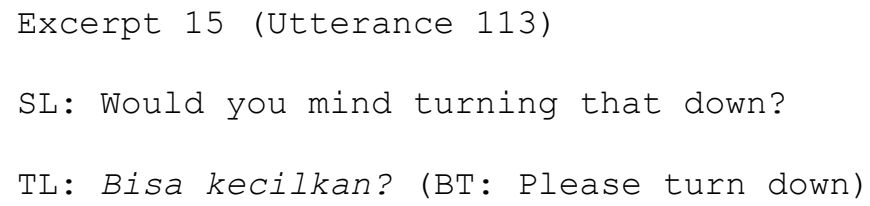

In the above excerpt, condensation is also used to shorten the subtitles yet still maintain the message that the speaker conveyed. In utterance 113, Lara Jean asked Peter to turn the volume of his radio that played a song, because she wanted to say something to him. The Indonesian subtitle matched the scene that brought a hectic atmosphere with a lot of noises coming from both Peter and his radio, not letting Lara Jean speak, thus she only had a few moments and fewer words to utter. The literal translation of the source language would be "Bisa kamu kecilkan itu?", leaving more words and being less natural because it sounds too formal for Indonesian spoken language.

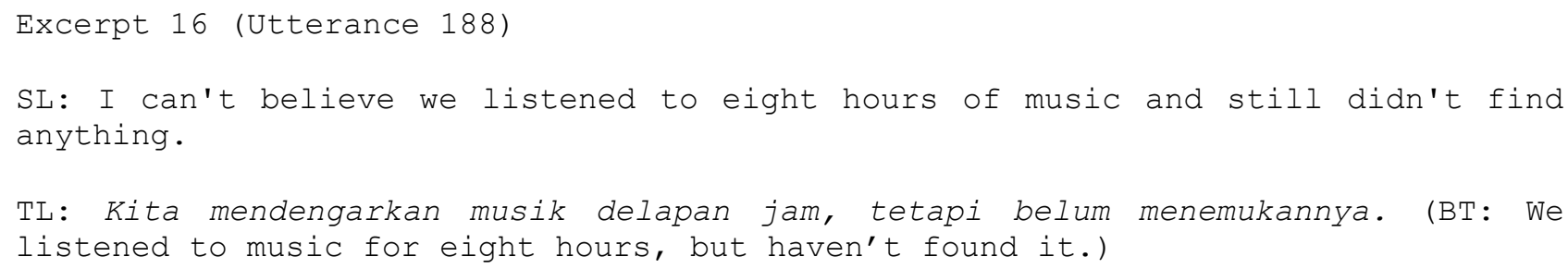

In the above excerpt, condensation is applied by the subtitler. Unnecessary words are omitted, and only the core message is maintained. The main idea of the utterance is that Lara Jean and Peter did not find the perfect song for them even after eight hours of listening to the music at the diner. The condensation is done by deleting the beginning and modifying the end part of the sentence, leaving the middle part which is the important part. "I can't believe" is dropped and "find anything" (BT: menemukan apapun) is changed to "menemukannya" (BT: find it). It makes the subtitles shorter and clearer for the audience.

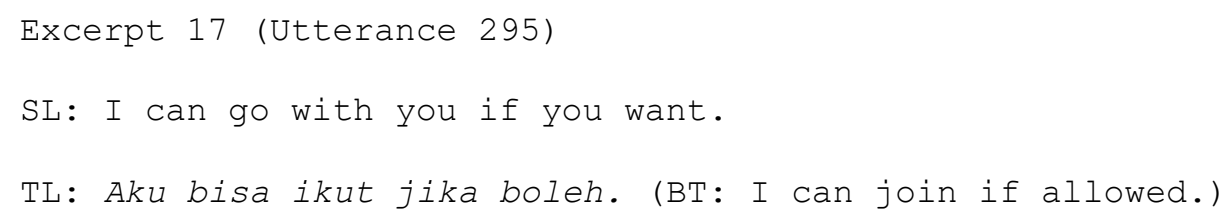

In Utterance 295, Lara Jean comforted Peter when his father asked him out for lunch. Peter's parents are divorced and Peter disliked his father because of it. Lara Jean offers her company if Peter wants. So, at the same time, she offered help and asked for Peter's permission to accompany him. The utterance "Aku bisa ikut jika boleh" covers both of her intentions, leaving appropriate and effective 
subtitles for the sentence "I can go with you if you want." The part of Lara Jean's utterance that is shortened is "with you if you want," as the subtitler changed it to "if allowed" to avoid the unnecessary word "you" that refers to Peter since it is obvious.

Excerpt 18 (Utterance 341)

SL: Do you have enough syrup?

TL: Siropmu cukup? (BT: Enough syrup?)

Similar to the paraphrase strategy, in the above excerpt, condensation is applied by the subtitler to obtain a shorter sentence but still have the same meaning. However, it is also to make the sentence natural in the Indonesian spoken language. The literal translation of the utterance would be "Apa kau memiliki cukup sirop?". Compared to "Enough syrup?", the literal translation not only has more words but also feels unnatural to the Indonesian audience because it is too formal for a spoken language.

\section{Deletion}

Deletion is done by omitting expressions that are considered not important. It can also be done when a fast speech of less importance occurs. In the film, there are 71 (16.59\%) of Lara Jean's utterances that are translated using deletion strategy. Amongst the 71 utterances, it was discovered that deletion aims to omit redundancy (49.30\%), filler words (25.35\%), repetition $(21.13 \%)$, and names (4.23\%). Below is an example of deletion strategy applied in subtitling the character's utterance:

Excerpt 19 (Utterance 75)

SL: They're still too crunchy.

TL: Masih terlalu renyah. (BT: Still too crunchy.)

In Utterance 75, Lara Jean complained to her father about her failed dough. She attempted to make a wedding cake for her father and her stepmom's wedding. Her dough is too crunchy for a cake. In the Indonesian subtitles, the subtitler omitted the pronoun "they" and the verb "are" because it is clear that the thing that is "still too crunchy" is Lara Jean's cake. In addition, in Indonesian, the pronoun "they" is not for things, only for people and animals. The deletion, in this case, is therefore due to language-bound (Cintas \& Ramael, 2021). Therefore, the deletion strategy is suitable to be applied in translating this utterance to avoid redundancy.

Excerpt 20 (Utterance 85)

SL: Kitty, you can't just ask that.

TL: Kau tak boleh meminta. (BT: You can't ask.)

The subtitler omitted names in the Indonesian subtitles if it is clear whom the speaker is talking to. In the above excerpt, Lara Jean's little sister's name, Kitty, is omitted because it is obvious that Lara Jean is talking to her. The scene of utterance 85 took place at the dining table consisting of Lara Jean, Kitty, their father, and their stepmother. When talking, Lara Jean turned her head to Kitty, making it visible that she was talking to Kitty. 


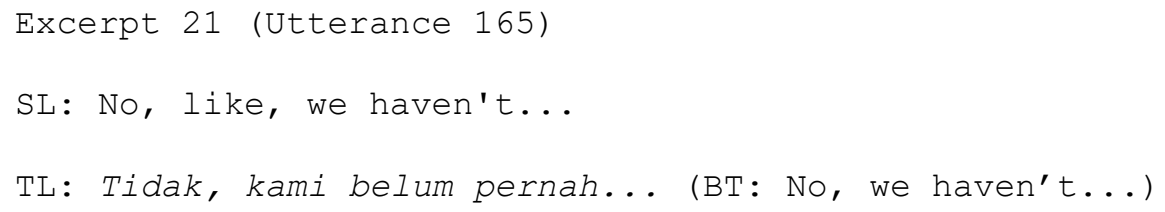

The subtitler omitted filler words in the Indonesian subtitles. Filler words, such as "I mean," "you know," "like," "uh," and "um," are common in spoken conversation. The context for utterance 85 is when Lara Jean admitted to her best friend, Christine, that she has never made love with Peter. The filler word "like" suggests that Lara Jean is avoiding the conversation because she is shy. It echoes Laserna, Seih, and Pennebaker who stated that the filler word "like" is usually uttered "as a hedge when they do not want to fully commit to what they say (Laserna et al., 2014).

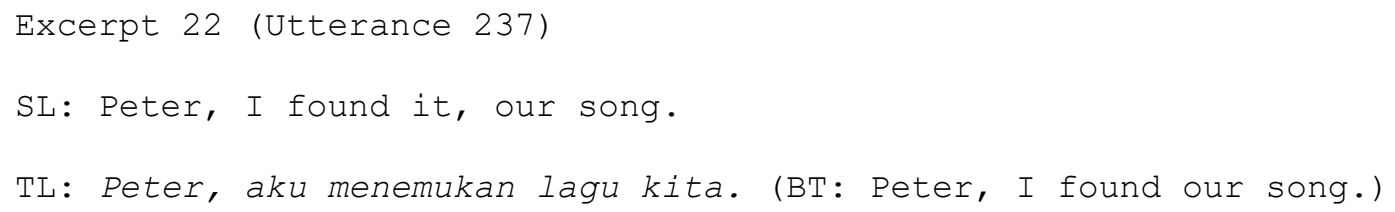

In the above excerpt, the word "it" refers to "our song", which is mentioned after that. The subtitler applied the deletion strategy by removing the word "it" to avoid repetition. The word "it" is not translated since it is clear what Lara Jean meant to say, which is about Peter and her song. Deleting the word "it" does not change the meaning of the utterance, yet it makes the final result an effective and accurate sentence.

\section{Imitation}

Imitation is used for translating proper nouns and international greetings. The characters for this strategy are the use of identical expressions as well as equivalent rendering. According to Shirinzadeh $\&$ Mahadi, proper nouns that do not possess specific meaning or cause difficulties for the audience are suitable to be maintained and therefore translated using imitation strategy (Shirinzadeh \& Mahadi, 2014). In the film, imitation is applied to greetings, characters' names, university names, places, and movie titles that are discovered in $33(7.71 \%)$ of Lara Jean's utterances. The findings are explained briefly through an example below:

Excerpt 23 (Utterance 9)

$\mathrm{SL}: \mathrm{Hi}$ !

TL: Hai!

"Hi" is a widely used greeting in many countries. According to Oxford Learner's Dictionary, it first emerged in late Middle English and is a natural exclamation that is uttered to greet someone ("Hi," n.d.). In Utterance 9, Lara Jean was in a video call with Peter because they were in different countries. She greeted Peter as soon as she answered the call. The Indonesian word for "hi" is "hai," which is pronounced the same, /haI/. Imitation, therefore, is used to translate greetings such as "hi" that is found in Utterance 9 above.

Excerpt 24 (Utterance 68)

SL: Berkeley and UCLA, and NYU.

TL: Berkeley, UCLA, dan NYU. 
In Utterance 68, Lara Jeans told Lucas, her friend, the name of the university that she applied to, besides Stanford. The name of the university is Berkeley, UCLA, and NYU. University names are proper nouns. Those university names, therefore, are translated using imitation and rewritten with the same spelling.

Excerpt 25 (Utterance 221)

\section{SL: Time Square!}

TL: Time Square!

The context of Excerpt 25 above is when Lara Jean and her best friend, Christine, were strolling around New York and visited some city icons. They recorded and took pictures in each of the places that they went to, including the famous tourist attraction, Times Square. Lara Jean smiled from ear to ear and yelled "Time Square!" in the video she recorded, which later was sent to Peter. Time Square is the name of a place, so it is a proper noun that is translated using the imitation strategy. So, the subtitles are written the same.

Excerpt 26 (Utterance 307)

SL: Kitty, what is this?

TL: Kitty, apa ini?

Imitation is used to transfer proper nouns. According to Oxford Learner's Dictionary, a proper noun means "a word that is the name of a person, a place, an institution, etc., and is written with a capital letter." Kitty is the name of Lara Jean's younger sister. In Excerpt 19, Kitty hid Lara Jean's acceptance letter from New York University because she thought her sister was going to Berkeley. Lara Jean soon discovered the hidden letter and asked Kitty for clarification. The word "Kitty", therefore, is a proper noun that stays the same in the target language.

Excerpt 27 (Utterance 314)

SL: New York has all the greats. You've Got Mail, When Harry Met Sally, Annie Hall, Serendipity.

TL: Banyak film hebat berlatar New York. You've Got Mail, When Harry Met Sally, Annie Hall, Serendipity.

In Utterance 314, Lara Jean compared some movies that were set in San Francisco and New York while talking to Peter. She then accentuated that New York has more great romances compared to San Francisco. In other words, she implicitly mentioned her intention to go to New York University, even though she will be very far away from Peter. In Excerpt 16, the proper nouns mentioned are movie titles. According to IMDb (Internet Movie Database), "You've Got Mail" was released in 1998, "When Harry Met Sally" was released in 1989, "Annie Hall" was released in 1977, and "Serendipity" was released in 2001. The subtitler used the imitation strategy to translate those movie titles because proper nouns stay the same in the target language.

\section{Expansion}

Expansion means adding necessary information to expand the expression, generally due to the culture-specific references that are not available in the target language. There is one $(0.23 \%)$ Lara 
Jean's utterances found in the film that is translated using expansion strategy. To elaborate and illustrate the findings, an example is presented below:

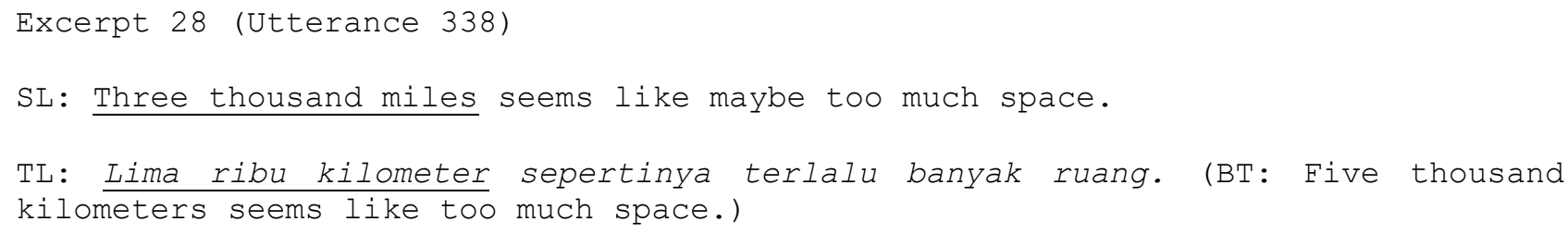

In the above excerpt, Lara Jean was worried and thinking whether or not Peter and she could still be in a relationship if she chose to go to New York University while Peter goes to Stanford. At night when everyone in the house was asleep, she shared her doubts with her father when he went downstairs to grab a glass of water. They were having a conversation in the kitchen as she emphasized that the distance between them will be three thousand miles. In Indonesia, miles as a distance measurement is not commonly used. Instead, Indonesians often used kilometers. The subtitler applied an expansion strategy to adjust to Indonesian culture that uses kilometers rather than miles and converts the numbers.

\section{Transcription}

Transcription is applied for non-standard speech such as third or non-sense language. It is found in one $(0.23 \%)$ of Lara Jeans' utterances in the film. The excerpt in the following shows the implementation of transcription strategy:

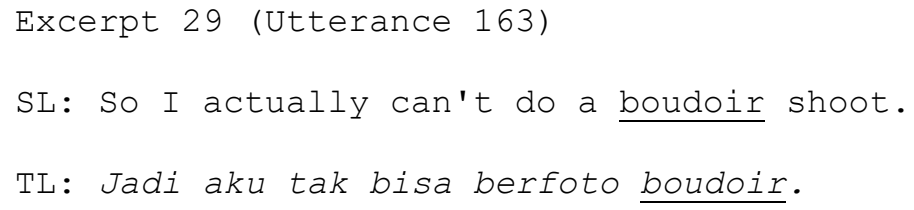

In Utterance 163, Christine, Lara Jean's best friend, jokingly told Lara Jean that she could do a boudoir shoot for Peter when they were in a long-distance relationship as they went to different campuses. Lara Jean responded to the joke by saying the fact that because she was only 17 , she could not do a boudoir shoot. Transcription is applied in Excerpt 8 above, where the word "boudoir" is mentioned. Boudoir, according to the Oxford Learner's Dictionary, means "a woman's small private room or bedroom" ("Boudoir," n.d.). It is a French term, which makes it a third language in the film. Therefore, it stays the same in the subtitle.

\section{Subtitle Quality}

Within this part, the subtitle quality assessment is carried out. Employing the theory from Nababan the analysis focused on the subtitle quality in the English-Indonesian subtitles of To All The Boys: Always \& Forever on Netflix (Nababan, 2012). The expert judgment forms were handed to four expert judges, who were all subtitles in a private company. The parts below illustrated the results for each of the subtitle quality assessments. 


\section{Accuracy Level}

Table 2 Accuracy Level in Lara Jean's utterances in "To All the Boys: Always and Forever" Subtitle on Netflix

\begin{tabular}{lll}
\hline Category & Number of Data & Percentage \\
\hline Accurate & 295 & $68.93 \%$ \\
Less accurate & 105 & $24.53 \%$ \\
Inaccurate & 28 & $6.54 \%$ \\
\hline Total data & 428 & $100 \%$ \\
\hline
\end{tabular}

Table 2 above shows the results of the accuracy level based on the forms that were distributed to four expert judges. From the 428 Lara Jean's utterances, 295 or $68.93 \%$ of them are translated accurately. As for the less accurate level, there are 105 utterances, or $24.53 \%$ of the total 428 utterances. Meanwhile, there are 28 or $6.54 \%$ of Lara Jean's utterances that were translated inaccurately. Therefore, it is safe to say that the subtitles of Lara Jean's utterances were mostly accurate.

\section{Acceptability Level}

Table 3 Acceptability Level in Lara Jean's utterances in "To All the Boys: Always and Forever" Subtitle on Netflix

\begin{tabular}{lll}
\hline Category & Number of Data & Percentage \\
\hline Acceptable & 361 & $84.35 \%$ \\
Less acceptable & 40 & $9.35 \%$ \\
Unacceptable & 27 & $6.31 \%$ \\
\hline Total data & 428 & $100 \%$ \\
\hline
\end{tabular}

Referring to Table 3, there were 361 or $84.35 \%$ of Lara Jean's utterances subtitles that were acceptable. Meanwhile, there were 40 or $9.35 \%$ of the utterances that were considered less acceptable. There were 27 or $6.31 \%$ unacceptable subtitles of the utterances. In conclusion, the subtitles of Lara Jean's utterances in the film were acceptable.

\section{CONCLUSION}

Subtitles are an interesting and important topic to study. Not only because people are watching more films since streaming platforms are getting more popular during a pandemic, but also to give access to people with hearing impairment for them to enjoy the film as much as the hearers do.

Referring to the statistical findings in the above discussion presents, it can be concluded that from the subtitling strategies proposed by Gottlieb, the paraphrase strategy is the most frequently used strategy with $28.50 \%$ or 122 utterances, while expansion and transcription are the least common strategy with $0.23 \%$ or one utterance on both strategies, and decimation, dislocation (Gottlieb, 1992), as well as resignation are not used in subtitling "To All the Boys: Always and Forever."

Paraphrase is the most frequently used strategy in subtitling the film because the subtitler needed to adjust the words of the sentence so it is shorter, effective, and accurate, but maintained the message. This result answers the question of what the most frequent subtitling strategy is and why so. On the other hand, expansion and transcription are the least used strategies, considering the film only mentioned one cultural reference and one-third language. In addition, decimation is not applied due to the film's PG-13 rating as it contains no taboo words. Resignation is not used either since there are 
no untranslatable words or phrases, as all of Lara Jean's utterances are translated properly using the seven strategies. Meanwhile, dislocation is not applied because the object of the research, which is the main character named Lara Jean, did not utter any songs in the film, thus musical and visual language-specific phenomena are not found. The Indonesian subtitle of the film is therefore enjoyable because the use of subtitling strategies helps the audience to grasp the message of the utterance without losing time to read it and not watch the scenes. In the matter of subtitle quality, it can be concluded that the subtitles are accurate and acceptable. Therefore, the strategies are well-executed.

Hopefully, this research can contribute to the translation and subtitling fields, as well as spark other researchers to do similar research to complement the existing ones. Additionally, through this research, subtitlers can enhance their skill by applying those strategies to their works. Further researches are advised due to the limitation of this research, which is only examining the main character of one film. Thus, further research is suggested to discover further and deeper analysis, specifically on the subtitle quality to gain more interesting and impactful results. Moreover, the research can also be continued using more data. The data can be improved by involving not only the main character, but also other speakers, adding the two other films in this trilogy, or focusing on the translation of the songs in the film. With more comprehensive data, it is expected to bring more accurate results on the subtitling strategies employed by Netflix. Lastly, a newer theory is hopefully available to then be applied to the latest films from various genres in the rising streaming platforms.

\section{REFERENCES}

Abdelaal, N. (2019). Subtitling of Culture-bound Terms: Strategies and Quality Assessment. Heliyon, 5(4), 1-27. https://doi.org/10.1016/j.heliyon.2019.e01411

Adinusa, H., \& Asmarani, R. (2018). Subtitling Strategies of Po's Utterances in Kung Fu Panda Movie. E-Structural (English Studies on Translation, Culture, Literature, and Linguistics), 1(1), 70-87. http://publikasi.dinus.ac.id/index.php/estructural/article/view/1825/0

Almeida, P., \& Costa, P. (2014). Foreign Language Acquisition: The Role of Subtitling. Procedia Social and Behavioral Sciences, 1234-1238. https://doi.org/10.1016/j.sbspro.2014.05.212

Altahri, A. (2013). Issues and strategies of subtitling cultural references Harry Potter movies in Arabic. University of Salford.

As you were. (n.d.). In Collins English Dictionary.

Atmowardoyo, H. (2018). Research Methods in TEFL Studies: Descriptive Research, Case Study, Error Analysis, and R \& D. Journal of Language Teaching and Research, 9(1), 197-204. https://doi.org/10.17507/jltr.0901.25

Boudoir. (n.d.). In Oxford Learner's Dictionaries.

Bowen, G. (2009). Document Analysis as a Qualitative Research Method. Qualitative Research Journal, 9(2), 27-40. https://doi.org/10.3316/QRJ0902027

Cintas, J. (2012). Subtitling: Theory, Practice and Research. In C. Millán \& F. Bartrina (The Routledge Handbook of Translation Studies. Routledge. 
Cintas, J., \& Ramael, A. (2021). Subtitling: Concepts and practices. Routledge. www.routledge.com/Translation-Practices-Explained/book-series/TPE

Dhari, P., Suarnajaya, W., \& Suwastini, N. (2016). An Analysis of Subtitling Strategy in the La La Land Movie. Jurnal Pendidikan Bahasa Inggris, 5(2). https://doi.org/10.23887/jpbi.v5i2.15053

Fareh, S., \& Moussa, M. (2008). Pragmatic Functions of Interrogative Sentences in English: A Corpus-based Study. International Journal of Arabic-English Studies (IJAES), 9(1), 145-164. http://www.ijaes.net/article/viewarticle?volume=9\&issue $=1 \&$ articleId $=8$

George, M. (2008). The Elements of Library Research: What Every Students Needs to Know. Princeton University Press.

Gottlieb, H. (1992). Subtitling - A New University Discipline. In C. Dollerup \& A. Loddegaard (Eds.), Teaching Translation and Interpreting: Training, Talent and Experience. John Benjamins Publishing Company.

Gottlieb, H. (2001). Texts, Translation and Subtitling-in Theory, and in Denmark. In Translators and Translations. Aarhus Universitetsforlag.

Halim, H., \& Asmarani, R. (2019). Procedures Used in Translating Cultural Words of the Movie Eat Pray Love. Jurnal Bahasa, Sastra, Dan Budaya, 15(2), 217-248. http://publikasi.dinus.ac.id/index.php/lite/article/view/2975/1706

Hariyanto, S. (2005). Subtitling: Di Antara Keterbatasan Bahasa-Budaya dan Media (Seklias Tinjauan). International Conference on Translation: Translation, Discourse, and Culture.

Hastuti, E. (2015). An Analysis On Subtitling Strategies Of Romeo And Juliet Movie. REGISTER JOURNAL, $8(1)$, $57-80$. https://journalregister.iainsalatiga.ac.id/index.php/register/article/view/324/257

Hosseinnia, M. (2014). Strategies in Subtitling English Cartoons or Animations. International Journal of Language Learning and Applied Linguistics World, 5(3), 128-135. http://citeseerx.ist.psu.edu/viewdoc/summary?doi=10.1.1.428.7017

Hudi, A., Hartono, R., \& Yuliasri, I. (2020). Subtitling Techniques and the Quality of Indonesian Subtitles of The English Teacher. English Education Journal, 10(456-465). https://doi.org/10.15294/eej.v10i4.39284

Khalaf, B. (2016). An Introduction to Subtitling: Challenges and Strategies. Journal of English Language, Literature, and Translation Studies, 3(1), 122-129. https://www.researchgate.net/publication/324921121

Kholiq, M., \& Agustine, E. (2020). Subtitling Strategies in "The Boss Baby: Back in Business" Series. Ethical Lingua, 7(1), 22-27. https://doi.org/10.30605/25409190.156

Laserna, C., Seih, Y., \& Pennebaker, J. (2014). Um... Who Like Says You Know: Filler Word Use as a Function of Age, Gender, and Personality. Journal of Language and Social Psychology, 33(3), 328-338. https://doi.org/10.1177/0261927X14526993 
Matkivska, N. (2014). Audiovisual Translation: Conception, Types, Characters' Speech and Translation Strategies Applied. Studies about Languages, 25, 38-44. https://doi.org/10.5755/j01.sal.0.25.8516

Nababan, M. (2012). Teori Menerjemah Bahasa Inggris. Pustaka Pelajar.

Paraphrase. (n.d.). In Oxford Learner's Dictionaries.

Pérez-González, L. (2014). Audiovisual Translation Theories, Methods and Issues. Routledge Ebooks.

Puri, D., \& Pasaribu, T. (2019). Pubg Fansubtitle: Strategies and Translation Acceptability. Journal of Language and Literature, 19(2), 126-139. https://doi.org/10.24071/joll.v19i2.2142

Rating Guide. (2020).

Richards, T. (2021). Predicting the future of the entertainment industry post-covid. USC News. https://news.usc.edu/183870/future-of-entertainment-after-covid-movies-tv-streaming-uscexperts/

Rohmawati. (2021). Subtitling Strategies of Swear Words in Deadpool One \& Deadpool Two Film. Indonesian Journal of EFL and Linguistics, 6(1), 17-36. http://publikasi.dinus.ac.id/index.php/lite/article/view/1093

Shirinzadeh, S., \& Mahadi, T. (2014). Translating Proper Nouns: A Case Study on English Translation of Hafez's Lyrics. English Language Teaching, 7(7), 8-16. https://doi.org//10.5539/elt.v7n7p8

Simanjuntak, N., \& Basari, A. (2016). Subtitling Strategies in Real Steel Movie. LITE: Jurnal Bahasa, Sastra, Dan Budaya, 12(1), 17-36. 